\title{
LARGE MAMMALS IN THE NORTH: CLIMATE CHANGE AND BOTTOM UP AND TOP DOWN INFLUENCES
}

\author{
Frank F. Mallory*, David M. A. Wiwchar, Tracy L. Hillis \\ Department of Biology, Laurentian University, Sudbury, Ontario P3E 2C6, Canada \\ *corresponding author \\ E-mail: fmallory@laurentian.ca
}

\begin{abstract}
The literature indicates a continued controversy whether ungulate populations are controlled from the bottom-up or the top-down and whether wolf predation is beneficial removing sick and unfit individuals or detrimental, driving populations into the so-called "predator pit". A macro-ecological approach was used to address these questions supporting the following conclusions: ungulates have evolved at the biome spatial scale, late and early succession specialists occur in each biome, one is larger and one is smaller, historically wolves occurred in all North American biomes as primary predators of ungulates, wolves specialize on the most common ungulate species, wolves change morphologically in relation to the size of their primary prey, pack size changes in relation to the size of their primary prey, wolf predation can be beneficial or detrimental depending upon the numerical and size relationship between the ungulate species in the system. Climate changes such as fire, drought and insect infestation will create early successional habitat increasing early successional specialists numbers and decreasing late successional ungulate population numbers. Bottom-up and top-down forces exist in all populations where wolves occur and managers need policies that support the smaller sized ungulate in the ecosystem, if they want to maintain both species at stable or increasing population levels.
\end{abstract}

Keywords: climate change, wolves, caribou, ungulates, top-down and bottom-up influences.

\section{INTRODUCTION}

Caribou (Rangifer tarandus) are medium-sized members of the Family Cervidae (Miller, 1982). Five subspecies of $R$. tarandus existed in North America in recent times: Peary's caribou (R. t. pearyi) from the High Arctic, the barren-ground caribou (R. t. groenlandicus) from the Low Arctic and Baffin Island, the montane or Grant's caribou (R. t. granti) from the northern Rocky Mountains and Alaska, the woodland caribou (R. t. caribou) that inhabits the boreal forest biome and the southern Rocky Mountains of British Columbia and the Queen Charlotte Island caribou $(R$. t. dawsoni) that is extinct (Banfield, 1974).

In each of these biomes or eco-zones, subspecies of caribou are sympatric with one other ungulate species; High Arctic (Peary's caribou and muskoxen) and Low Arctic Tundra biome (barren-ground caribou and muskoxen), the Boreal Forest biome (woodland caribou and moose) and the northern montane boreal zone (Grant's/woodland caribou and moose) (Banfield, 1974; Bergerud, 1974; Mallory, Hillis, 1998). Currently, in some of these biomes or eco-zones, caribou numbers are in decline and at low numbers (predator pit), while the populations of other

(C) Mallory Frank F., Wiwchar David M. A., Hillis Tracy L., 2019 ungulates are high, stable or increasing. In other biomes, caribou populations have recently been high, stable and increasing and still represent the most abundant ungulate in the system (Mallory, Hillis, 1998), while the populations of other ungulates in the system are also stable or increasing. The debate whether ecosystems are structured from the top-down, predator driven, or from the bottom-up, food or resource driven, has been discussed for nearly a century and remains controversial (Hairston et al., 1960; Estes, 1996; Kay, 1998). In the past, this was not always the case as muskoxen (Ovibus moschatus) populations in the Low Arctic Tundra were decimated by over-hunting by the end of the 1800 s and all the great barren-ground herds crashed in this region and reached low numbers in the mid to late 1950s and early 1960s (Banfield, 1974; Bergerud, 1974; Mallory, Hillis, 1998).

In the Boreal Forest biome in Ontario, few moose (Alces alces) existed north of Lake Superior and in the northeast prior to the mid-1800s (Krefting, 1974) and since that time moose have increased and woodland caribou have retreated northward to the approximate limit of commercial timber harvest (Racey et al., 1991). Moose have benefited from early succession forests created by timber harvest (Krefting, 1974; Haggstrom, 1994; Karns, 1998). Indeed, 
when we analyze the wolf/ungulate systems in all the biomes of North America, we see that these systems are dynamic and continually changing.

In North America, sympatric ungulates have historically coexisted and shared resources in all biomes with the exception of the Coastal Plain and the West Indian biomes, which were one ungulate ecosystems' maintained in early successional habitat, due to frequent fires and flooding (Gleason \& Conquist, 1964; Darby et al., 1989). In the other 8 North American biomes, resource partitioning and patchy environments facilitate the coexistence of two sympatric ungulates, an early and late successional specialist (Stelfox, Taber, 1969; Hudson, 1976; Boer, 1992).

Wolves like other predators often search for less risky opportunities rather than attack larger, more dangerous prey (Mech, 1970; Forbes, 1989; Weaver et al., 1992). We hypothesized that risk to wolves' increases with prey size. Since larger ungulate prey would expose wolves to higher levels of risk of injury or death (Weaver et al., 1992; Mallory et al., 1994), we hypothesize that natural selection would favor larger wolves in habitats dominated by larger ungulates and smaller wolves in habitats dominated by smaller ungulates. We also suggest that wolves specialize on the most common ungulate in the system. If the larger ungulate is dominate, the increased numbers of wolves (pack size) and selection for larger wolves adapted to killing larger more dangerous prey (i. e.: moose) would subject the smaller less common ungulate to increased predation risk and ultimately population decline to a possible predator pit. Similarly, when the smaller prey is more abundant, natural selection would drive the morphology of the predator to a smaller size (less food) and pack size and the larger, less common prey would present a more dangerous prey choice and would tend to be avoided by the predator, resulting in sustained or increasing populations of the larger prey species.

Previous work done in the Keewatin District, N. W. T. (currently Nunavut), on wolf populations along the western coast of Hudson Bay in the Low Arctic Tundra has established that wolf size and degree of sexual dimorphism is correlated with primary prey body mass (Hillis, 1990; Mallory, Hillis, 1995; Mulders, 1997). As a result, this study investigated the influence of early and late successional habitat on ungulate species dominance within two ungulate species biome systems (bottom-up influences) and the morphological and numerical adaptations of wolves to shifts in primary ungulate prey population abundance (top-down influences), with comments on other ungulate carnivore specialists.

\section{METHODS}

A macro-ecology analysis of wolf/ungulate relationships across North America was done to assess the relative interaction and influence of bottom- up and top-down impacts on ungulate systems as these issues remain controversial (Brown, Mallory, 2007).

\section{Bottom-Up Influences}

A review of the general historical floral and faunal composition, changes in the major biomes and eco-zones of North America was done to assess impacts on ungulate systems (Gleason, Cronquist, 1964). Bottom-up influences include forage availability and forage specialization in ungulates and spatially and temporally changes that influence early and late successional habitat created by natural and anthropogenic impacts (Hillis, Mallory, 1989; Metsaranta et al., 2003; Donovan et al., 2017). The impact of biome extensions, ecotones and eco-zones on species composition was also assessed. Eco-zones were defined as regions such as altitudinal zoning on mountains throughout the Cordilleran biome and divisions such as the High Arctic and Low Arctic Tundra regions, which have different faunal and floral complexes.

\section{Top-Down Influences}

A review of the historical distribution of the primary predators throughout the North American biome system was undertaken to distinguish the topdown impacts of the different predators on ungulate populations. This included the large felids such as the cougar (Felis concolor) and the jaguar (Panthera onca), the ursids (Ursus americanus and U. arctos) and the wolf complex (Canis lupus / C. lycaon / C. latrans) (Wilson et al., 2000, 2009). The literature indicates a continued controversy whether ungulate populations are controlled from the bottom-up or the top-down and whether predation is beneficial removing sick and unfit individuals or detrimental, driving populations into the so-called "predator pit" (Mech, 1970; Wilkinson and Shank, 1976; Bergerud, Elliot, 1986; Messier, 1994, 1995; Seip, 1992; Carbyn et al., 1993; Forbes, Theberge, 1996).

\section{RESULTS AND DISCUSSION}

\section{Biome Structure}

North America has 10 biomes or floristic provinces including the Tundra Biome, Boreal Forest Biome, Eastern Deciduous Forest Biome, Coastal Plain Biome, West Indian Biome, Prairie Biome, Cordilleran Biome, Great Basin Biome, California Biome and the Sonoran Biome (Gleason, Cronquist, 1964). As Gleason and Cronquist (1964) noted, the actual boundaries between biomes are not sharp and overlap and inter-finger extensively, with small enclaves of one province often being wholly surrounded by another. These ecotonal regions most often support species from both biomes and as a result, increases in species richness occur (Popp et al., 2018). In addition, each biome has "biome extensions" primarily along riparian and montane systems that interdict with adjacent biomes and provide habitat for species from adjacent biomes. 
In the Low Arctic Tundra, moose (Alces alces) that have followed the boreal forest extension north along the Thelon River have been shot near Baker Lake, Nunavut; however, no one considers moose an arctic tundra species (R. Mulders, pers. comm.). Similarly, white-tailed deer (Odocoileus virginianus), a denizen of the Eastern Deciduous Forest biome is associated with the treed bottomlands of tributaries of the Mississippi River system that cross the Prairie biome and not the open grassland ecosystem (Hesselton, Hesselton, 1982).

If we remove the ungulate species associated with biome extensions and the ecotones, then historically each biome had two ungulate species, with the exception of the Coastal Plain and West Indian biomes, which were maintained in "early successional stages by frequent fire and flooding (Gleason, Cronquist, 1964). In each of the other 8 systems, one ungulate was an "early successional specialist" and the other was a "late successional specialist" and one ungulate was larger and one was smaller in size.

In the High Arctic Tundra eco-zone, the early successional specialist is the muskoxen $(O$. moschatus) foraging primarily on sedges and the late successional specialist is Peary's caribou ( $R$. taran$d u s$ pearyi) foraging primarily on lichens. In the Boreal Forest biome, the moose (A. alces) is the early successional specialist foraging primarily on aquatic plants and woody browse (Renecker, Hudson, 1986), while the woodland caribou ( $R$. tarandus $c a-$ ribou) is the late successional specialists foraging primarily on lichens and terrestrial herbaceous plants (Darby, Pruitt, 1984; Proceviat et al., 2003). In the Prairie biome, pronghorn (Antilocapra americana) were the early successional specialist foraging primarily on browse, forbs and other dicotyledonous plants (Kitchen, O'Gara, 1982), while the bison (Bison bison) was the late successional specialist foraging primarily on monocotyledonous grasses (Reynolds et al., 1982; Lott, 2002). Indeed, when we consider all the biomes and eco-zones, we find two ungulate systems with an early and late successional specialist of different body mass (Table 1).

\section{Bottom-Up Control}

All evidence supports the conclusion that bottom-up factors are the primary influence dictating whether the early or late successional specialist is the most common ungulate species in the system. In the High Arctic Tundra ecozone is dominated by sedges, which are in access of $40 \%$ of the forage available to ungulates on Truelove Lowland, Devon Island, Nunavut, utilized extensively by the early successional specialist, the muskoxen, while lichens, especially large mats of Cladonia and Cetaria typical of Low Arctic Tundra and utilized extensively by the late successional specialist, Peary's caribou are very limited (Muc, Bliss, 1977; Svoboda, 1977; Richardson, Finegan, 1977; Russell, Edmonds, 1977; Mallory, Boots, 1983). Therefore, in contrast to the Low Arctic Tundra ecozone, muskoxen are the most common ungulate in the system and Peary's caribou are rare and even considered endangered (COSEWIC, 2004; D. Jenkins, per. comm.). In contrast, extensive lichen mats dominate the Low Arctic Tundra ecozone and boreal / tundra subarctic ecotone, while sedge communities are limited in this system (Muc, Bliss, 1977; Svoboda, 1977; Richardson, Finegan, 1977). As a result, the Low Arctic Tundra is dominated by barrenground caribou and muskoxen are the less common species (Mallory, Hillis, 1998).

Historically, woodland caribou were the dominate species in mature boreal forest and found on the southern edge of the coniferous forest (Krefting, 1974); however, as logging proceeded northward from the 1900 s creating early successional habitat, woodland caribou range receded northward and in Ontario with few exceptions is only found north of 50 degrees latitude (Brown et al., 2003; Wiwchar, Mallory, 2012; Fig. 1). As the forest became dominated by birch and aspen, the early successional spe-

Table 1. North American biomes and ecozones and their historical early and late successional ungulate species, excluding ungulate species associated with biome extensions and ecotones

Таблица 1. Биомы и экозоны Северной Америки и их исторически поздние и ранние сукцессионные виды копытных, за исключением видов копытных, связанных с расширением биомов и экотонов

\begin{tabular}{|l|l|l|}
\hline \multicolumn{1}{|c|}{ Specialization } & \multicolumn{1}{c|}{ Late } & \multicolumn{1}{c|}{ Early } \\
\hline Alpine Tundra & Bighorn Sheep & Mountain Goat \\
\hline Montane Boreal Ecozone & Woodland/Grant's & Caribou Moose \\
\hline Montane Deciduous Ecozone & Elk & Mule/Black-tailed Deer \\
\hline High Arctic Tundra Ecozone & Peary's Caribou & Muskoxen \\
\hline Low Arctic Tundra Ecozone & Barren-ground Caribou & Muskoxen \\
\hline Boreal Forest Biome & Woodland Caribou & Moose \\
\hline Eastern Deciduous Forest Biome & Elk & White-tailed Deer \\
\hline Prairie Biome & Bison & Pronghorn \\
\hline Great Basin Biome & Mule Deer & Pronghorn \\
\hline California Biome & Tule Elk & Mule Deer \\
\hline Desert Biome & Collared Peccary & White-tailed Deer \\
\hline
\end{tabular}


cialist the moose became the dominant species in the southern logged regions of the Boreal Forest biome and woodland caribou were extirpated (Krefting, 1974; Cumming, 1992; Cumming, Beange, 1993; Chubbs et al., 1993; Haggstrom, 1994; Antoniak, Cumming, 1996; Hillis et al., 1998; Karns, 1998; Wiwchar, Mallory, 2012).

Similar historical results are evident for the Eastern Deciduous Forest biome, which was clear-cut from northern Florida to the north-central parts of Ontario and Quebec to make farms. Even though both ungulates in this system were hunted with no restrictions until the early 1900s, the late successional specialist, the elk Cervus canadensis was extirpated, while the early successional specialist, the white-tailed deer survived and is now economically the most important antlered species in North America. Similar histories exist for all the other biomes across the continent with major shifts in ungulate populations and species dominance associated with bottom-up changes primarily driven by natural (Edwards, 1954; Schaefer, Pruitt, 1991) and anthropogenic change (Mallory, Hillis, 1998; Brown et al., 2007; Metsaranta, Mallory, 2007).

\section{Top-Down Control}

A number of mammalian predators have evolved specializations on ungulate prey throughout North America. These included the ursids (U. americanus and $U$. arctos), which are primarily seasonal predators preying on calves in early spring (Franzmann et al., 1980; Craighead, Mitchell, 1982; Pelton, 1982), although adult ungulates are occasionally taken (Austin et al., 1994; Obbard et al., 2000) and the large felids, which are perennial predators but highly specialized and do not inhabit all biomes (Sunquist, Sunquist, 1989). The cougar (Felis concolor), preys primarily on deer and other cervids (Hornocker, 1970) and the jaguar (Panthera onca), speciali

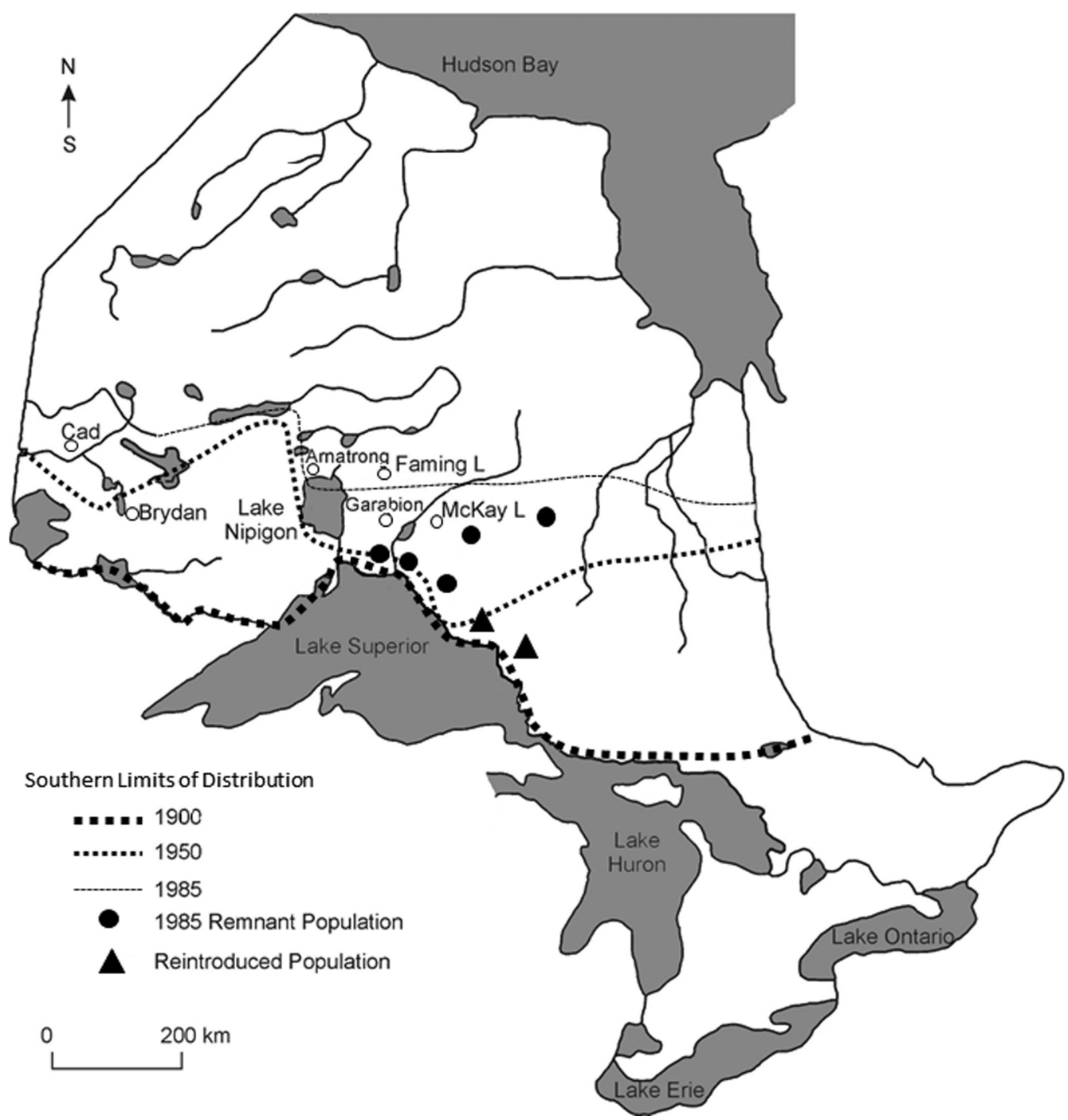

Fig. 1. Historical distribution of woodland caribou (Rangifer tarandus caribou) in Ontario from 1900 to 1985 (Racey et al., 1991)

Puc. 1. Историческое распределение лесного карибу (Rangifer tarandus caribou) в Онтарио в 1900-1985 гг. (Racey et al., 1991) 
zes largely on peccary and to a lesser extent deer and capybara (Emmons, 1987).

However, the North American wolf complex (Canis lupus / C. lycaon / C. latrans) and their hybrids is unique (Brewster, Fritts, 1995; Crete, Desrosiers, 1995; Dale et al., 1995; Wilson et al., 2000, 2009), historically inhabited all biomes from the High Arctic Tundra to the Deserts of southwestern United States and northern Mexico (Hall, 1981). Additionally, they were perennial predators specializing on ungulates in all seasons and utilized all ungulate species in North America from the large bison on the prairies to the small peccary in the deserts (Fig. 2). Each of these prey species provided differences in body mass, nutrient availably and levels of risk.

A survey of the literature over the past many years yields two distinct and opposing hypotheses

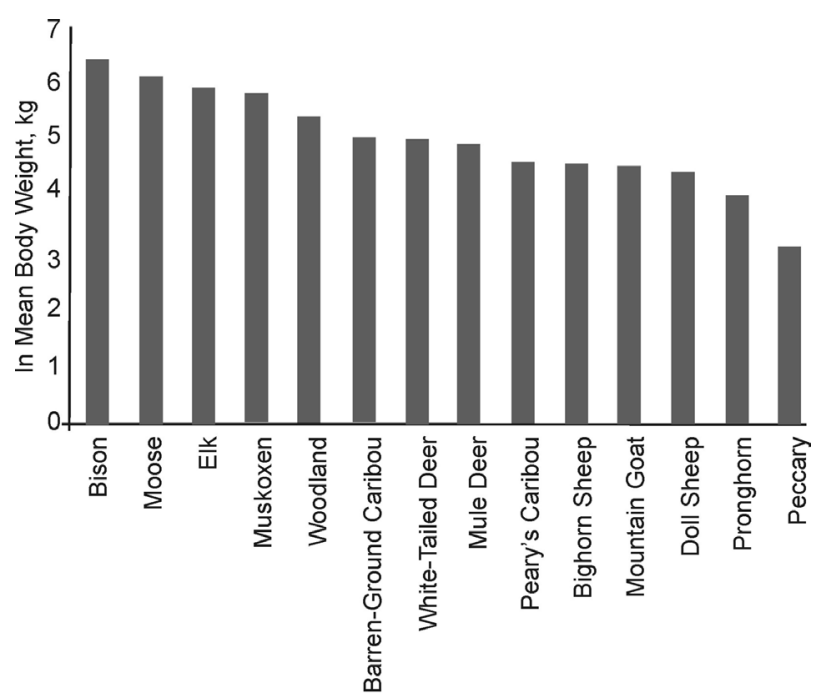

Fig. 2. Variation in $\ln$ mean body weight $(\mathrm{kg})$ in North American ungulate species and subspecies historically utilized by wolves

Puc. 2. Вариативность логарифма средней массы тела (кг) видов и подвидов копытных Северной Америки, исторически употребляемых в пищу волками

related to wolves and associates: (1) that wolves maintain healthy sustainable ungulate populations by primarily killing weak and sick individuals and thus reducing disease and poor genetic stock and (2) that wolves consume ungulates in all stages of health and drive populations into a "predator pit" (Mech, 1970; Bergerud, Elliot, 1986; Seip, 1992; Carbyn et al., 1993; Messier, 1994, 1995; Forbes, Theberge, 1996). These two hypotheses provide us with four possible options, which may be correct: (1) wolves create healthy sustainable ungulate populations, (2) wolves drive ungulate populations into a predator pit; (3) both options 1 and 2 are correct, and (4) neither options 1 and 2 are correct.

In addition, data indicates wolves specialize on the most common ungulate in the system, whether large

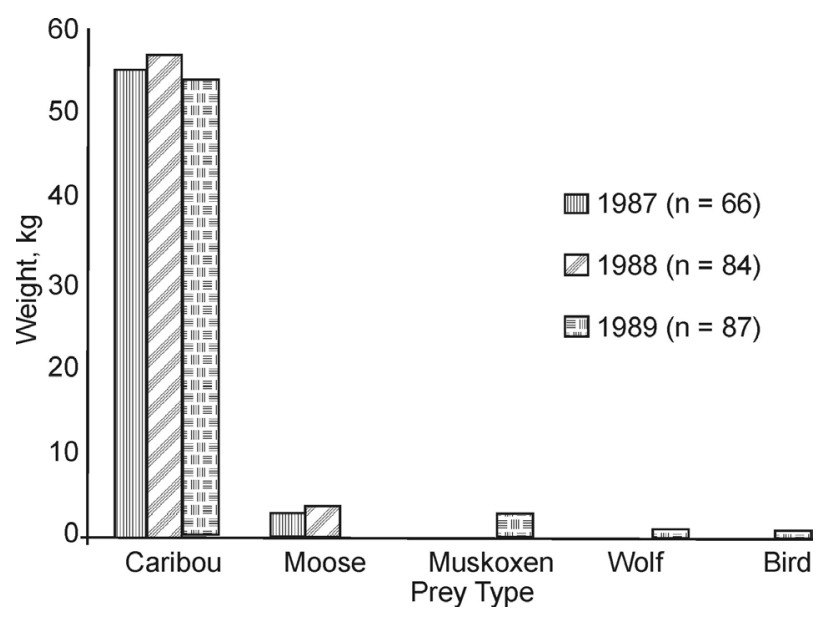

Fig. 3. Stomach contents of wolves between 1987 and 1989 along the west coast of Hudson Bay, Canada in the range of the Kaminuriak caribou herd, which numbered 400.000 plus animals at the time, while the muskoxen population approximated 4.000 animals (Lamothe, Parker, 1989)

Puc. 3. Содержимое желудков волков в 19871989 гг. на западном побережье Гудзонова залива (Канада), на угодьях стада карибу Каминуриак, которое в этот период насчитывало более 400000 голов при том, что поголовье овцебыка в то же время составляло примерно 4000 животных (Lamothe, Parker, 1989)

or small, regardless of prey body mass or risk of injury (Mech, 1970; Bergerud, Elliot, 1986; Forbes, 1989; Lamothe, Parker, 1989; Seip, 1992; Carbyn et al., 1993; Messier, 1994, 1995). Fig. 3 illustrates the utilization of prey by wolves along the west coast of Hudson Bay, Canada in the range of the Kaminuriak caribou herd, which numbered 400.000 plus animals at the time (R. Mulders, pers. comm.), while the muskoxen population approximated 4.000 animals (Lamothe, Parker, 1989). Clearly, wolves are killing prey of all sizes, but specializing on the most common species.

In this study, it was found that sexual dimorphism in wolves (mean male body mass/mean female body mass) varied significantly in relation to the mean body mass of the primary ungulate prey (Hillis, Mallory, 1996; Fig. 4). Hall (1981) identified 24 gray wolf subspecies (C. lupus) and 3 red wolf subspecies (C. rufus) throughout North America that occurred historically, which likely evolved in relation to the size and risk associated with different prey species and subspecies. Similar morphological differences have been found more recently for wolves associated with different prey species in different parts of Canada (Kolenosky, Stanfield, 1975; Schmitz, Kolenosky, 1985; Schmitz, Lavigne, 1987; Nowak, 1995; Mallory, Edwards, 1996; Mulders, 1997).

Pack size was also found to change with changes in ungulate prey body mass as illustrated in Fig. 5 (Stenlund, 1955; Mech, 1970, 1977; Kolenosky, 1972; Fuller, Keith, 1980a,b; Fritts, Mech, 


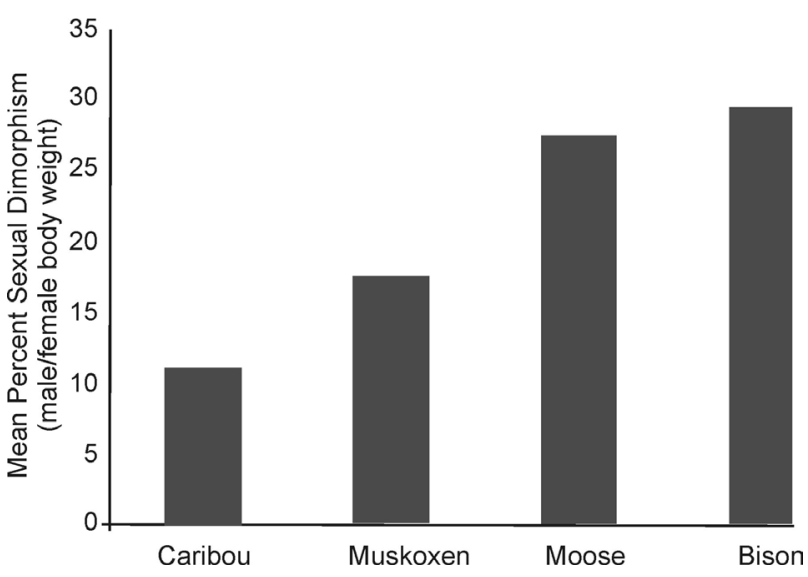

Fig. 4. Mean percent sexual dimorphism (male / female body weight $\times 100)$ in wolves associated with different primary ungulate prey $(\mathrm{kg})$

Puc. 4. Средний процент полового диморфизма (масса тела самца / самки $\times 100)$ у волков в связи с различными видами основной копытной добычи (кг)

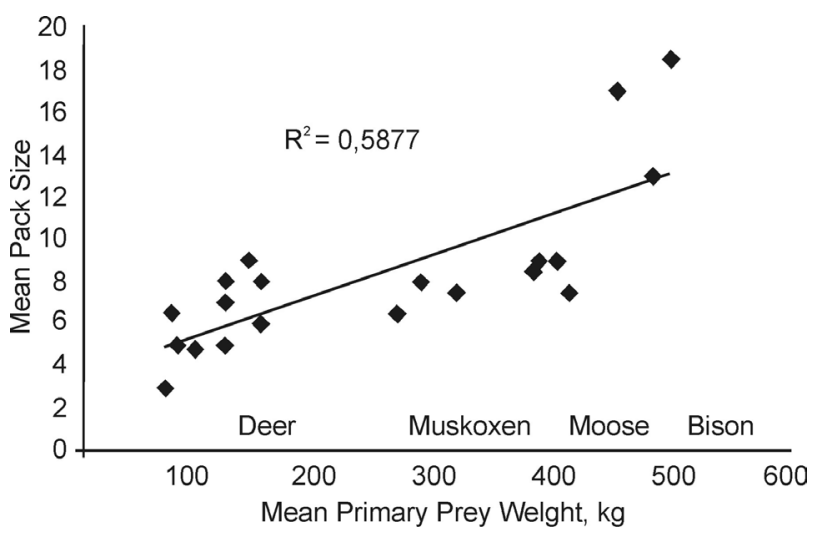

Fig. 5. Mean wolf pack size in relation to the mean body weight $(\mathrm{kg})$ of their primary ungulate prey

Puc. 5. Средний размер волчьей стаи в отношении к средней массе тела (кг) ее основной копытной добычи

1981; Peterson et al., 1984; Ballard et al., 1987; Carbyn et al., 1993; Dale et al., 1994).

Table 2 illustrates the population dynamics and relationship between the common and rarer ungulate species in extant ecosystems in the northern part of the continent, where wolves still exist. These data show that in wolf/ungulate systems where the larger ungulate is the most common, the population of the smaller ungulate species decreases or goes into a predator pit. In contrast, when the smaller ungulate species is most common, the populations of the larger ungulate are stable or increasing. These results support the conclusion that management policy that sustains the smaller ungulate in the system in wolf/ungulate systems will maintain the populations of both ungulate species.

The results support conclusions that in wolf/ungulate systems:
1. Ungulates have evolved at the biome spatial scale,

2. Where wolves still occur, both bottom-up and top-down factors interact to influence ungulate population sustainability and risk of extirpation,

3 . Each biome has two ungulate species,

4. One is the early successional specialist and the other is the late successional specialist,

5. One ungulate is always larger and the other smaller in body mass,

6 . Wolves specialize on the most common ungulate in the system,

7. Wolf body mass increases with increased ungulate body mass,

8. Wolf pack size increases with increased ungulate body mass,

9. If the largest ungulate is most common, the population of the smaller ungulate will decline to low numbers (predator pit) due to increased susceptibility to predation by larger more numerous wolves,

10. If the smallest ungulate is most common, the population of the larger ungulate will increase or be stable, due to reduced susceptibility to predation by smaller less numerous wolves,

11. Both hypotheses are correct that wolves can drive ungulate populations into a predator pit or sustain ungulate populations by removing sick and weak individuals from the population,

12. One species ungulate systems have evolved historically in biomes where limiting natural factors (fire, flooding) maintained only early successional habitat (the Coastal Plain and West Indian Biomes) and

13. One species ungulate systems have evolved recently in biomes where anthropogenic disturbance has maintain only early successional habitat (the Eastern Deciduous Forest and Prairie Biomes).

14. Four species ungulate systems have evolved in ecotone regions between biomes (Cairns, Telfer, 1980) and

15. If wildlife managers promote the smaller ungulate through bottom-up or top-down policies or by limiting the larger ungulate population, both ungulate species will be sustained.

16. Fires, drought and insect infestations in the West will be larger, more intense and of greater duration creating early successional habitat favouring moose and reducing caribou populations

17. Fires etc. in the East Central region will be smaller, less intense and shorter duration creating late successional habitat favouring caribou and moose populations will decline in the nearer future, assuming humans do not continue to interfere (forestry).

\section{ACKNOWLEDGEMENTS}

Financial support was provided by Northwest Science and Technology Unit (Ontario Ministry of Natural Resources, Thunder Bay, Ontario), Lauren- 
Table 2. Population dynamics of primary ungulate prey in wolf predator/prey systems throughout_North America (status - increasing/stable +: decreasing/threatened -)

Таблица 2. Популяционная динамика основной копытной добычи в системе хищник - добыча волка на территории Северной Америки (статус: увеличение/стабильность +; уменьшение/угроза -)

\begin{tabular}{|c|c|c|c|c|c|}
\hline Location & Common Prey & Status & Rarer Prey & Status & Researchers \\
\hline High Arctic Is. & Muskoxen & + & Caribou & - & M. Ferguson, pers. comm. \\
\hline Banks Island & Muskoxen & + & Caribou & - & Wilkinson, Shank, 1976 \\
\hline $\begin{array}{l}\text { MacKenzie } \\
\text { Reserve }\end{array}$ & Bison Bison & + & Moose & - & C. Gates, pers. comm. \\
\hline $\begin{array}{l}\text { Wood Buffalo } \\
\text { National Park }\end{array}$ & Bison & + & Moose & - & Carbyn et al., 1993 \\
\hline $\begin{array}{l}\text { British Columbia } \\
\text { (South-East) }\end{array}$ & Moose & + & Caribou & - & Seip, 1992 \\
\hline British Columbia & Moose & + & Caribou & - & Bergerud, Elliot, 1986 \\
\hline $\begin{array}{l}\text { Alberta } \\
\text { (Northeast) }\end{array}$ & Moose & + & Caribou & - & Fuller, Keith, 1981 \\
\hline $\begin{array}{l}\text { Ontario } \\
\text { (Northwest) }\end{array}$ & Moose & + & Caribou & - & Racey et al., 1991 \\
\hline $\begin{array}{l}\text { Ontario } \\
\text { (French River) }\end{array}$ & Moose & + & Elk & - & J. Hamr, pers. comm. \\
\hline $\begin{array}{l}\text { Ontario } \\
\text { (Northeast) }\end{array}$ & Moose & + & Caribou & - & C. Davies, pers. comm. \\
\hline $\begin{array}{l}\text { Quebec } \\
\text { (North) }\end{array}$ & Caribou & + & Moose & + & $\begin{array}{l}\text { Brassard et al., } 1974 \\
\text { Messier, 1994, } 1995\end{array}$ \\
\hline $\begin{array}{l}\text { Cape Lisburne } \\
\text { (Alaska) }\end{array}$ & Caribou & + & Muskoxen & + & Jingfors, Klein, 1982 \\
\hline $\begin{array}{l}\text { Low Arctic } \\
\text { (Keewatin) }\end{array}$ & Caribou & + & Muskoxen & + & $\begin{array}{l}\text { R. Mulders, pers. comm. } \\
\text { A. Fleich, pers. comm. }\end{array}$ \\
\hline $\begin{array}{l}\text { Low Arctic } \\
\text { (Yukon) }\end{array}$ & Caribou & + & Moose & + & A. Fleich, pers. comm. \\
\hline $\begin{array}{l}\text { Ontario } \\
\text { (Loring) }\end{array}$ & Deer & + & Moose & + & T. J. Bellhouse, pers. comm. \\
\hline $\begin{array}{l}\text { Ontario } \\
\text { (Algonquin Park) }\end{array}$ & Deer & + & Moose & + & Forbes, Theberge, 1996 \\
\hline Minnesota & Deer & + & Moose & + & D. Mech, pers. comm. \\
\hline
\end{tabular}

Pearson Chi-square: $\mathrm{X}^{2}=14.00 ; \mathrm{P}<0.0002$.

tian University, Abitibi Consolidated Incorporated, Bowater Pulp and Paper Incorporated, Buchanan Forest Products Incorporated, Domtar Forest Products Incorporated and Kimberly-Clark Forest Products Incorporated.

\section{REFERENCES}

Antoniak, F.; Cumming, H. G., 1996, Analysis of Forest Stands Used by Wintering Woodland Caribou in Ontario, Rangifer Spec. Iss., 10, 157-168.

Austin, M. A.; Obbard, M. E.; Kolenosky, G. B., 1994, Evidence for a Black Bear, Ursus americanus, Killing an Adult Moose, Alces alces, Can. Field-Nat., 108, 236-238.

Ballard, W. B.; Whitman, J. S.; Gardner, C. L., 1987, Ecology of an Exploited Wolf Population in South-Central Alberta, Wildl. Monogr., 98, 353-360.

Banfield, A. W. F., 1974, The Mammals of Canada, University of Toronto Press, Toronto.

Bergerud, A. T., 1974, Decline of Caribou in North America Following Settlement, J. Wildl. Manage., 38, 757-770.
Bergerud, A. T.; Elliot, J. P., 1986, Dynamics of Caribou and Wolves in Northern British Columbia, Can. J. Zool., 64, 1515-1529.

Boer, A. H., 1992, History of Moose in New Brunswick, Alces, 1, 16-21.

Brewster, W. G.; Fritts, S. H., 1995, Taxonomy and Genetics of the Gray Wolf in Western North America: a Review, Ecology and Conservation of Wolves in a Changing World, Eds. L. N. Carbyn, S. H. Fritts, D. R. Seip, Canadian Circumpolar Institute, Occasional Publication, 35, 353-373.

Brown, G. S.; Mallory, F. F., 2007, A Review of Ungulate Nutrition and the Role of Top-Down and BottomUp Forces in Woodland Caribou Population Dynamics, NCASI, Techn. Bull., 934, 1-94.

Brown, G. S.; Mallory, F. F.; Rettie, W. J., 2003, Range Size and Seasonal Movement for Female Woodland Caribou in the Boreal Forest of Northeastern Ontario, Rangifer, Spec. Iss. 14, 227-233.

Brown, G. S.; Rettie, W. J.; Brooks, R. J.; Mallory, F.F., 2007, Predicting the Impacts of Forest Management 
on Woodland Caribou Habitat Suitability in Black Spruce Boreal Forest, For. Ecol. Manage., 245, 137-147.

Cairns, A. L.; Telfer, E. S., 1980, Habitat Use by Four Sympatric Ungulates in Boreal Mixedwood Forest, $J$. Wildl. Manage., 45, 849-857.

Carbyn, L. N.; Oosenbrug, S. M.; Anions, D. W., 1993, Wolves, Bison and the Dynamics Related to the Peace-Athabasca Delta in Canada's Wood Buffalo National Park, Circumpolar Research Series, 4, Canadian Circumpolar Institute, University of Alberta Press, Edmonton.

Chubbs, T. E.; Keith, L. B.; Mahoney, S. P.; McGrath, M. J., 1993, Responses of Woodland Caribou (Rangifer tarandus caribou) to Clear-Cutting in East-Central Newfoundland, Can. J. Zool., 8, 87-493.

COSEWIC, 2004, Canadian Species at Risk, Canadian Wildlife Service, Environment Canada.

Craighead, J. J.; Mitchell, J. A., 1982, Grizzly Bear, Wild Mammals of North America: Biology, Management and Economics, Eds. J. A. Chapman, G. A. Feldhamer, The John Hopkins University Press, Baltimore, 515-556.

Crete, M.; Desrosiers, A., 1995, Range Expansion of Coyotes, Canis latrans, Threatens a Remnant Herd of Caribou, Rangifer tarandus, in Southeastern Quebec, Can. Field-Nat., 9, 227-235.

Cumming, H. G., 1992, Woodland Caribou: Facts for Forest Managers, For. Chron., 68, 481-491.

Cumming, H. G.; Beange, D. B., 1987, Dispersion and Movements of Woodland Caribou Near Lake Nipigon, Ontario, J. Wildl. Manage., 51, 69-79.

Cumming, H. G.; Beange, D. B., 1993, Survival of Woodland Caribou in Commercial Forests of Northern Ontario, For. Chron., 69, 579-588.

Dale, B. W.; Adams, L. G.; Bowyer, R. T., 1994, Functional Response of Wolves Preying on Barren-Ground Caribou in a Multiple-Prey Ecosystem, J. Anim. Ecol., 63, 644-652.

Dale, B. W.; Adams, L. G.; Bowyer, R. T., 1995, Winter Wolf Predation in a Multiple Prey System: Gates of the Arctic National Park, Alaska, Ecology and Conservation of Wolves in a Changing World, Eds. L. N. Carbyn, S. H. Fritts, D. R. Seip, Alberta, Canadian Circumpolar Institute, Occasional Publication, 35, 642.

Darby, W. R.; Pruitt Jr., W. O., 1984, Habitat use, Movements and Grouping Behaviour of Woodland Caribou, Rangifer tarandus caribou, in Southeastern Manitoba, Can. Field-Nat., 98, 184-190.

Darby, W. R.; Timmermann, H. R.; Snider, J. B.; Abraham, K. F.; Stefanski R. A.; Johnson, C. A., 1989, Woodland Caribou in Ontario: Background to a Policy, Ontario Ministry of Natural Resources, Toronto, Ontario.

Donovan V. M.; Brown G. S.; Mallory F. F., 2017, The Impacts of Forest Management Strategies for Woodland Caribou Vary Across Biogeographic Gradients, PLoS ONE, 12, 2, e0170759, DOI:10.1371/journal. pone.0170759.

Edwards, R. Y., 1954, Fire and the Decline of a Mountain Caribou Herd, J. Wildl. Manage., 18, 512-526.

Emmons, L. H., 1987, Comparative Feeding Ecology of Felids in a Neotropical Rainforest, Behav. Ecol. Sociobiol., 20, 271-283.

Estes, J. A., 1996, Predators and Ecosystem Management, Wildl. Soc. Bull., 24, 390-396.
Forbes, L. S., 1989, Prey Defenses and Predator Handling Behaviour: the Dangerous Prey Hypothesis, Oikos, $55,155-158$.

Forbes, G. J.; Theberge, J. B., 1996, Response by Wolves to Prey Variation in Central Ontario, Can.J. Zool., 74, 1511-1520.

Franzmann, A. W.; Schwartz, C. C.; Peterson, R. O., 1980, Moose Calf Mortality on the Kenai Peninsula, Alaska, J. Wildl. Manage., 44, 764-768.

Fritts, S. H.; Mech, L. D., 1981, Dynamics, Movements and Feeding Ecology of a Newly Protected Wolf Population in Northwestern Minnesota, Wildl. Monogr., 79, 470-491.

Fuller, T. K.; Keith, L. B., 1980, Summer Ranges, Cover-Type Use and Denning of Black Bears Near Fort McMurray, Alberta, Can. Field-Nat., 94, 80-83.

Fuller, T. K.; Keith, L. B., 1981, Wolf Predation and Prey Relationships on Northeastern Alberta, J. Wildl. Manage., 44, 582-602.

Gleason, H. A.; Cronquist, A., 1964, The Natural Geography of Plants, Columbia University Press, NY.

Haggstrom, D., 1994, Some Ramifications of Fire and Forest Management Policies on the Boreal Forest and Wildlife of Interior Alaska, Fire Effects in Alaska Workshop, Wainwright, Alberta.

Hairston, N. G.; Smith, F. E.; Slobodkin, L. B., 1960 , Community Structure, Population Control and Competition, Am. Nat., 94, 421-425.

Hall, E., 1981, The Mammals of North America, II, $2^{\text {nd }}$ ed., John Wiley and Sons, New York.

Hesselton, W. T.; Hesselton, R. M., 1982, WhiteTailed Deer, Wild Mammals of North America: Biology, Management and Economics, Eds. J. A. Chapman, G. A. Feldhamer, The John Hopkins University Press, Baltimore, 878-901.

Hillis, T. L., 1990, The Demography and Ecology of the Tundra Wolf, Canis lupus in the Keewatin District, Northwest Territories, M. Sc. Thesis, Laurentian University, Sudbury, Ontario.

Hillis, T. L.; Mallory, F. F., 1989, Interrelationship of Snow Depth to Primary and Secondary Predator/Prey Systems in the Tundra/Boreal Ecotone of the Keewatin/ Manitoba Region, Musk-Ox, 37, 137-143.

Hillis, T.L.; Mallory, F.F., 1996, Sexual Dimorphism in Wolves (Canis lupus) of the Keewatin District, Northwest Territories, Canada, Can. J. Zool., 74, 721-725.

Hillis, T. L.; Mallory, F. F.; Dalton, W. J.; Smiegielski, A. J., 1998, Preliminary Analysis of Habitat Utilization by Woodland Caribou in Northwestern Ontario Using Satellite Telemetry, Rangifer, Spec. Iss., 10, 195-202.

Hornocker, M. G., 1970, An Analysis of Mountain Lion Predation Upon Mule Deer and Elk in the Idaho Primitive Area, Wildl. Monogr., 21, 1-39.

Hudson, R. J., 1976, Resource Division within a Community of Large Herbivores, Nature Canada, 103, 153-167.

Karns, P.D., 1998, Population Distribution, Density and Trends, Ecology and Management of the North American Moose, Eds. A. W. Franzmann, C. C. Schwartz, Smithsonian Institution Press, Washington, D. C., 125-140

Kay, C.E., 1998, Are Ecosystems Structured from the Top-Down or Bottom-Up: a New Look at an Old Debate, Wildl. Soc. Bull., 26, 484-498.

Kitchen, D. W.; O'Gara, B. W., 1982, Pronghorn, Wild Mammals of North America: Biology, Management and 
Economics, Eds. J. A. Chapman, G. A. Feldhamer, The John Hopkins University Press, Baltimore, 960-971.

Kolenosky, G. B., 1972, Wolf Predation on Wintering Deer in East-Central Ontario, J. Wildl. Manage., 36, 357-369.

Kolenosky, G. B.; Stanfield, R. O., 1975, Morphological and Ecological Variation among Gray Wolves (Canis lupus) of Ontario, Canada, The Wild Canids, their Systematics, Behavioural Ecology and Evolution, Ed. M. W. Fox, Van Nostrand Reinhold Company, New York, 62-72.

Krefting, L. W., 1974, Moose Distribution and Habitat Selection in North American, Nature Canada, 1010, 81-100.

Lamothe, A. R.; Parker, G. H., 1989, Winter Feeding Habits of Wolves in the Keewatin District, Northwest Territories, Canada, Musk-Ox, 37, 144-149.

Lott, D. F., 2002, American Bison: A Natural History, University of California Press, Berkeley.

Mallory, F. F.; Boots, B. N., 1983, Spatial Distribution of Lemming Mats in the Canadian High Arctic, Can. J. Zool., 61, 99-107.

Mallory, S. E.; Edwards, C., 1996, A Comparison of Standard Measurements and Fractal Techniques for Distinguishing Gray Wolves (Canis lupus) and Coyotes (Canis latrans), B. Sc. (Hons.) Thesis, Laurentian University, Sudbury, Ontario.

Mallory, F. F.; Hillis, T. L., 1995, Correlations of Sexual Dimorphism and Foraging Strategies in Wolves, Canis lupus, from the Central Canadian Arctic, International Symposium on Wolves and Humans 2000, Univ. Minnesota, Duluth.

Mallory, F. F.; Hillis, T. L., 1998, Demographic Characteristics of Circumpolar Caribou Populations: Ecotypes, Ecological Constraints / Releases, and Population Dynamics, Rangifer, Spec. Iss., 10,49-60.

Mallory, F. F.; Hillis, T. L.; Blomme, C. G.; Hurst, W. G., 1994, Skeletal Injuries of an Adult Timber Wolf, Canis lupus, in Northern Ontario, Can. Field-Nat., 108, 230-232.

Mech, L. D., 1970, The Wolf, Natural History Press, Garden City.

Mech, L. D., 1977, Population Trend and Winter Deer Consumption in a Minnesota Wolf Pack, Proceedings of the 1975 Predator Symposium, Montana Forest and Conservation Experiment Station, USDA Forest Service Research Paper NC-52, St. Paul, Minnesota, 55-83.

Mech, L. D., 2007, Annual Arctic Wolf Pack Size Related to Arctic Hare Numbers, Arctic, 60, 309-311.

Messier, F., 1985, Social Organization, Spatial Distribution and Population Density of Wolves in Relation to Moose Density, Can. J. Zool., 63, 239-245.

Messier, F., 1994, Ungulate Population Models with Predation: a Case Study with the North American Moose, Ecol., 75, 478-488.

Messier, F., 1995, Trophic Interactions in Two Northern Wolf-Ungulate Systems, Swed. Wildl. Res., 22, 131146.

Metsaranta, J. M.; Mallory, F. F., 2007, Ecology and Habitat Selection of a Woodland Caribou Population in West Central Manitoba, Canada, Northeast. Nat., 14, 571-588.

Metsaranta, J. M.; Mallory, F. F.; Cross, D. W., 2003, Vegetation Characteristics of Forest Stands Used by Woodland Caribou and Those Disturbed by Fire and Logging in Manitoba, Rangifer, Spec. Iss., 14, 255-266.
Miller, F. L., 1982, Dentition as an Indicator of Sex and Age; Composition and Socialization of the Populations, Biology of the Kaminuriak Population of BarrenGround Caribou, Part II, Canadian Wildlife Service Report Series, 1-88.

Muc, M.; Bliss, L. C., 1977, Plant Communities of Truelove Lowland, Truelove Lowland, Devon Island, Canada, Ed. L. C. Bliss, The University of Alberta Press, Edmonton, 143-154.

Mulders, R., 1997, Geographic Variation in the Cranial Morphology of the Wolf (Canis lupus) in Northern Canada, MSc. Thesis, Laurentian University, Sudbury, Ontario.

Nowak, R. M., 1995, Another Look at Wolf Taxonomy, Ecology and Conservation of Wolves in a Changing World, Eds. L. N. Carbyn, S. H. Fritts and D. R. Seip, Can. Circumpolar Inst., Occ. Publ., 35, 375-398.

Obbard, M. E.; Campbell, G. D.; Schenk, A., 2000, Evidence for Fatal Injury Inflicted on a Female Black Bear by a Moose, Northeast. Wildl., 55, 57-62.

Pelton, M. R., 1982, Black Bear, Wild Mammals of North America: Biology, Management and Economics, Eds. J. A. Chapman, G. A. Feldhamer, The John Hopkins University Press, Baltimore, 504-514.

Peterson, R. O.; Woolington, J. D.; Bailey, T. N., 1984, Wolves of the Kenai Peninsula, Alaska, Wildl. Monogr., 88, 267-281.

Popp, J. N., Hamr J.; Larkin J. L.; Mallory F. F., 2018, Black Bear (Ursus americana) and Wolf (Canis spp.) Summer Diet Composition and Ungulate Prey Selectivity in Ontario, Canada, Mammal Research, 1-9, DOI.org/10.1007/s13364-018-0368-y.

Proceviat, S. K.; Mallory, F. F.; Rettie, W. J., 2003, Estimation of Arboreal Lichen Biomass Available to Woodland Caribou in Hudson Bay Lowland Black Spruce Sites, Rangifer, Spec. Iss., 14, 95-99.

Racey, G. D.; Abraham, K.; Darby, W. R.; Timmermann, H. R.; Day, Q., 1991, Can Woodland Caribou and the Forest Industry Coexist: the Ontario Scene, Ibid., 7, 108-115.

Renecker, L. A.; Hudson, R. J., 1986, Seasonal Foraging Rates of Free-Ranging Moose, J. Wildl. Manage., 50, 143-147.

Rettie, W. J.; Messier, F., 1998, Dynamics of Woodland Caribou Populations at the Southern Limit of Their Range in Saskatchewan, Can. J. Zool., 76, 251-259.

Reynolds, H. W.; Glaholt, R. D.; Hawley, A. W. L., 1982, Bison, Wild Mammals of North America: Biology, Management and Economics, Eds. J. A. Chapman, G. A. Feldhamer, The John Hopkins University Press, Baltimore, 972-1007.

Richardson, D. H. S.; Finegan, E. J., 1977, Studies on the Lichens of Truelove Lowland, Truelove Lowland, Devon Island, Canada, Ed. L. C. Bliss, The University of Alberta Press, Edmonton, 245-262.

Russell, R. H.; Edmonds, E. J., 1977, Caribou and Muskoxen Habitat-Prince of Wales and Somerset Islands and Booth Peninsula, Canadian Wildlife Service, Fisheries and Environment Canada, Preliminary Report, ESCOM, AI-11, 1-83.

Schaefer, J. A.; Pruitt Jr., W. O., 1991, Fire and Woodland Caribou in Southeastern Manitoba, Wildl. Monogr., $116,1-39$.

Schmitz, O. J.; Kolenosky, G. B., 1985, Wolves and Coyotes in Ontario: Morphological Relationships and Origins, Can. J. Zool., 63, 1130-1137. 
Schmitz, O. J.; Lavigne, D. M., 1987, Factors Affecting Body Size in Sympatric Ontario Canids, J. Mammal., 68, 92-99.

Schwartz C. C.; Franzmann, A. W., 1991, Interrelationship of Black Bears to Moose and Forest Succession in the Northern Coniferous Forest, Wildl. Monogr., 113, $1-58$.

Seip, D. R., 1992, Factors Limiting Woodland Caribou Populations and Their Interrelationships with Wolves and Moose in Southeastern British Columbia, Can. J. Zool., 70, 1494-1503.

Stelfox, J. G.; Taber, R. D., 1969, Big Game in the Northern Rocky Mountains Coniferous Forest, Coniferous Forests of the Northern Rocky Mountains, Ed. R. D. Taber, University of Montana Foundation, Montana.

Stenlund, M. H., 1955, A Field Study of the Timber Wolf (Canis lupus) on the Superior National Forest, Minnesota, Tech. Bull., 4, Minnesota Department of Conservation, St. Paul, Minnesota.

Sunquist, M. E.; Sunquist, F. C., 1989, Ecological Constraints on Predation by Large Felids, Carnivore Behavior, Ecology, and Evolution, 1, Ed. J. L. Gittleman, Comstock Publ. Assoc., Cornell University Press, Ithaca, 283-301.
Svoboda, J., 1977, Ecology and Primary Production of Raised Beach Communities, Truelove Lowland, Truelove Lowland, Devon Island, Canada, Ed. L. C. Bliss, The University of Alberta Press, Edmonton, 185-216.

Weaver, J. L.; Arvidson, C.; Wood, P., 1992, Two Wolves, Canis lupus, Killed by a Moose, Alces alces, in Jasper National Park, Alberta, Can. Field-Nat., 106, 126127.

Wilkinson, P. F.; Shank, C. C., 1976, Muskox-Caribou Summer Range Relations on Banks Island, N. W. T., J. Wildl. Manage., 40, 151-162.

Wilson, P. J.; Grewal, S. K.; Lawford, I. D.; Heal, J. N. M.; Granacki, A. G.; Pennock, D.; Theberge, J. B.; Theberge, M. T.; Voigt, D. R.; Waddell, W.; Chambers, R. E.; Paquet, P. C.; Goulet, G.; White, B. N., 2000, DNA Profiles of the Eastern Canadian Wolf and the Red Wolf Provide Evidence for a Common Evolutionary History Independent of the Gray Wolf, Can. J. Zool., 78, 2156-2166.

Wilson, P. J.; Grewal, S. K.; Mallory, F. F.; White, B. N., 2009, Genetic Characterization of Hybrid Wolves Across Ontario, J. Hered., 100, 80-89.

Wiwchar, D. M. A.; Mallory, F. F., 2012, Prey Specialization and Morphological Conformation of Wolves Associated with Woodland Caribou and Moose, Rangifer, Spec. Iss., 19, 309-328.

Received 24. 12. 2018

Received after revision 09. 02. 2019

\title{
КРУПНЫЕ МЛЕКОПИТАЮЩИЕ НА СЕВЕРЕ: КЛИМАТИЧЕСКИЕ ИЗМЕНЕНИЯ - НИСХОДЯЩЕЕ И ВОСХОДЯЩЕЕ ВОЗДЕЙСТВИЯ
}

\author{
Ф. Ф. Мэллори, Д. М. А. Вивчар, Т. Л. Хиллис
}

\author{
Департамент биологии, Лаврентийский университет, Садбери, Онтарио, Канада
}

В литературе давно ведутся споры о том, контролируются ли популяции копытных «снизу вверх» (т. е. запасом кормов) или «сверху вниз» (т. е. хищниками) и благотворно ли при этом влияние волка, уничтожающего больных и слабых особей, или же оно, напротив, вредно, поскольку ведет популяции жертв к деградации - в так называемую волчью яму. На основе макроэкологического (ландшафтного) подхода к этим вопросам сделаны следующие заключения: копытные эволюционировали в пространстве целостного биома; виды копытных, специализированные к условиям ранней и поздней стадий сукцессии, встречаются в каждом биоме, причем один из них более крупный, а другой - более мелкий; исторически волки в качестве главных хищников входили в состав экосистемы всех североамериканских биомов, специализируясь на питании наиболее многочисленными видами копытных; на индивидуальном уровне размер волков изменялся соответственно размеру предпочитаемой добычи; размер волчьей стаи также менялся в связи с величиной основной добычи; хищничество волка может быть как полезным, так и вредным в зависимости от численности и размера копытных, населяющих тот или иной биом. Климатические изменения, такие как лесные пожары, засухи и вспышки численности насекомых, увеличивают численность копытных, адаптированных к пионерным стадиям растительной сукцессии и снижают численность видов, приспособленных к ее более поздним стадиям. Восходящие и нисходящие взаимодействия существуют во всех популяциях копытных, на которых оказывают влияние волки, и охотоведам следует проводить политику поддержания более мелких видов копытных, если они хотят сохранить экосистему, включающую оба их вида в состоянии стабильной или возрастающей численности.

Ключевые слова: климатические изменения, волки, карибу, копытные, нисходящее и восходящее воздействие. 